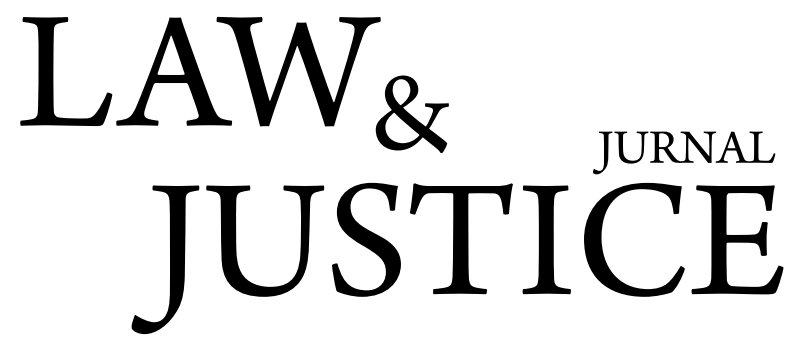

\title{
PENDEKATAN TEORI HUKUM REFLEKSIF DALAM MENJAWAB PERMASALAHAN KETERBATASAN PENGAWASAN TERHADAP PELAKSANAAN TANGGUNG JAWAB SOSIAL PERUSAHAAN DI INDONESIA
}

\author{
Satria Sukananda \\ Mahasiswa Program Magister Ilmu Hukum \\ Fakultas Hukum Universitas Islam Indonesia \\ Jln. Cik Ditiro No. 1 Yogyakarta \\ Email: Artisukananda@gmail.com
}

\begin{abstract}
Abstrak
Tanggung Jawab Sosial Perusahaan (Corporate Social Responsibility) telah diatur di dalam Undang-Undang Nomor 25 Tahun 2007 tentang Penanaman Modal dan Undang-Undang Nomor 40 Tahun 2007 Tentang Perseroan Terbatas, Namun dalam pelaksanaannya masih menimbulkan banyak masalah. Permasalahan pertama peraturan tersebut tidak mengatur secara rinci tentang pelaksanaan CSR. Permasalahan kedua adalah ketidakjelasan aturan dan mekanisme pengawasan pelaksanaan CSR itu sendiri. Hasil kajian ini menunjukan bahwa pendekatan teori hukum refleksif dapat menjawab permasalahan tersebut, CSR dapat wajibkan oleh pemerintah kepada setiap korporasi karena CSR tumbuh dan berkembang sesuai dengan perkembangan bisnis dan reaksi pasar, maka aturan dan mekanisme pengawasanya dengan mewajibkan korporasi untuk membuat laporan kepada masyarakat yang disebu laporan sosial (Social Reporting).
\end{abstract}

Kata kunci: Tanggung Jawab Sosial Perusahaan, Teori Hukum Refleksif, Mekanisme Pengawasan, Laporan Sosial

\section{Pendahuluan}

\section{Latar belakang}

David C. Korten dalam bukunya When Corporation Rule The World (1995) berucap, bahwa dalam paruh akhir abad keduapuluh terjadi perubahan yang luar biasa dari sejarah manusia. Temuan yang dicapai oleh ilmu pengetahuan telah menghantarkan perdaban menjadi sangat maju. Seperti terwujudnya perjalanan luar angkasa, computer, kecangguhan pengobatan hingga perlengkapan hidup sehari-hari. Ini semua dapat dinikmati oleh masyarakat karena industrialiasasi yang dilakukan oleh korporasi. Mereka memproduksi berbagai kebutuhan sehari-hari, menguasai jasa untuk hajad hidup orang banyak seperti listrik, air minum, pengangkutan, lembaga sekolah, rumah sakit, mengatur keuangan masyarakat serta 
aktifitas hidup lainya. Korporasi telah menjelma menjadi institusi yang sangat dominan mempengaruhi setiap kehidupan bangsa, bahkan melebihi kekuasaan Negara. Perihal inilah yang melahirkan wacana tanggung jawab sosial perusahaan (Corporate Social Responsibility), ${ }^{1}$ yang menjadi diskursus yang banyak diperbincangkan dalam berbagai kajian.

Dari perspektif ilmu hukum perusahaan, sesungguhnya perdebatan ini sudah dimulai pada 1930 an antara Adolf Berle dan Emerric Dood mengenai tujuan korporasi. Antara mencari keuntungan demi kepentingan kepemilikan (Share Holder) atau memperhatikan kepentingan masyarakat umum (Stake Holder)?. ${ }^{2}$ Namun hukum perusahaan diberbagai Negara masih menempatkan kepentingan share holder dalam kedudukan yang utama. Bahkan dalam kontek Corporate Social Responsibility (CSR), Milton Friedman, Penerima anugerah nobel bidang ekonomi mengatakan: "there is one and only one social responsibility of bussinese, to use its resource and engage in activities designed to increase it profits"

Seiring Perkembangan zaman, mulai muncul kesadaran dan pemikiran bahwa korporasi sebagai institusi bisnis tidak lagi semata-mata mencari keuntungan, tetapi juga melayani kepentingan sosial. Bryant Jr dan Susan E Mehrtens, menawarkan paradigma baru tujuan perusahaan dalam gelombang keempat (fourth wave) yang bertujuan untuk melayani masyarakat (serve as global steward). Juga munculnya konsep triple bottom lines, bahwa korporasi berujuan untuk mencari keuntungan (profit), menciptakan kesejahteraan sosial (people) dan melestarikan lingkungan hidup (planet).

Dalam dekade terakhir ini, Indonesia muncul tingkat kesadaran dan mengharapkan sesuatu yang lebih dari perusahaan atau korporasi. Perusahaan bukan lagi sebagai entitas yang hanya memetingkan dirinya sendiri saja atau mencari keuntungan (taking profit), melainkan sebuah entitas usaha yang wajib melakukan adaptasi dalam mengatasi permasalahan atau tekanan sosial yang muncul dalam masyarakat, khususnya masyarakat yang berada disekitar lingkungan perusahaan. Pemahaman ini lebih dikenal sebagai Tanggung Jawab Sosial Perusahaan (TJSP).

Dalam penerapan Tanggung Jawab Sosial Perusahaan Indonesia, pada awalnya memang bersifat sukarela (voluntary), wajar jika penerapannya pun bebas tafsir berdasarkan kepentingan masing-masing. Antara lain: program pengetasan kemiskinan perbaikan kesejahteraan, bantuan subsidi langsung dan sebagainya. Itu jika dilakukan oleh pemerintah sebagai unsur Negara yang mempunyai peran penting di situ.

Kenyataan menunjukkan bahwa upaya-upaya ini sering tidak membawa hasil atau berkelanjutan. Di samping itu, walaupun ada beberapa perusahaan yang melakukan aksi kepedulian sosial, baik berupa dana bantuan atau sembako korban bencana alam, panti asuhan, dan lain-lain. Sayangnya, berbagai bantuan ini masih terkesan haus publikasi tanpa menyentuh akar masalah yang sedang dihadapi oleh masyarakat. Seringkali bantuan tersebut hanya berguna sesaat saja, selanjutnya masyarakat kembali pada kondisi semula. ${ }^{4}$

Tanggung Jawab Sosial Perusahaan atau Corporate Social Responsibility (selanjutnya di tulis CSR), diatur secara tergas di Indonesia, dalam Undang-Undang 25 Tahun 2007 tentang Penanaman Modal, dan Undang-Undang Nomor 40 Tahun 2007 tentang Perseroan Terbatas. Hal ini dilatarbelakangi oleh Amanat Undang-Undang Dasar 1945 mengenai Perekonomian nasional dan kesejahteraan social ${ }^{5}$ selain itu berdasarkan prinsip pembangunan berkelanjutan, dalam hal ini lembaga legislative, berkeinginan

$\overline{1}$ Bowen (1953) mendefenisikan CSR adalah keputusan perusahaan untuk memberikan nilai-nilai positif bagi masyarakat. Davis (1973) mendefinisikan CSR sebagai usaha ikhlas dari perusahaan untuk menciptakan keseimbangan ekonomi dan keadaan sosial masyarakat yang baik.

2 Yang dimaksud dengan Stake Holder disini adalah pihak-pihak yang berkepentingan terhadap keberadaan perusahaan yang memengaruhi pada pemberian keputusan dan kebijakan perusahaan yang akan ditetapkan. Termasuk di dalamnya, yaitu pekerja, pemasok, pengguna, pemerintah sebagai pembuat peraturan, masyarakat, dan pemilik perusahaan itu sendiri (Frederick et al ., 1988:77)

3 Mukti Fajar ND, Tanggung Jawab Sosial Perusahaan di Indonesia Mandatory vs Voluntary Studi Tentang Penerapan Ketentuan Corporate Social Responsibility Pada Perusahaan Multi Nasional, Swasta Nasional dan Badan Usaha Milik Negara, Yogyakarta: Pustaka Pelajar, 2009

4 Badan Pembinaan Hukum Nasional Departemen Hukum dan Ham Republik Indonesia, Tanggung Jawab Sosial Perusahan, hal 3

5 Risalah Rapat Panitia Khusus, Rancangan Undang-Undang Tentang Perseroan Terbatas, Masa Sidang I, Jumat, 1 desember 2006 di dalam buku Mukti Fajar ND, Tanggung Jawab Sosial Perusahaandi Indonesia... op.cit hal 1 
untuk mencegah dan mengurangi rusaknya lingkungan yang diakibatkan oleh operasional korporasi yang tidak memperhatikan lingkungan hidup masyarakat disekitarnya. ${ }^{6}$

Corporate Social Responsibility Juga di atur didalam Pasal 15 huruf b Undang-Undang Nomor 25 Tahun 2007 Tentang Penanaman Modal yang didalam penjelasalannya menyebutkan bahwa: yang dimaksud dengan Tanggung Jawab Sosial Perusahaan adalah Tanggung Jawab yang melekat pada setiap perusahaan penanaman modal untuk menciptakan hubungan yang serasi, seimbang dan sesuai dengan lingkungan, nilai, moral, norma dan budaya masyarakat setempat. Sebagai Kosekuensi dan pengaturan tersebut, agar memiliki daya atur, daya ikat, dan daya paksa. Tanggung Jawab Perusahaan yang semula adalah Responsibility (Tanggung Jawab Non Hukum) akan berubah menjadi Liability (Tanggung Jawab Hukum). Dalam artian, Corporate Social Responsibility menjadi objek hukum yang dapat diikat dan dipaksakan, dan apabila tidak dilaksanakan akan mendapatkan sanksi. ${ }^{7}$

Kajian mengenai Tanggung Jawab Sosial Perusahaan di indonesia menjadi penting dilakukan karena regulasi mengenai Tanggung Jawab Perusahaan di Indonesia dan pelaksanaan nya masih menemui permasalahan. Permasalahan tersebut dapat dilihat dari segi regulasi pengawasan terhadap pelaksanaan Tanggung Jawab Sosial Perusahaan (Corporate Social Responsibilty), Dewasa ini Pengawasan terhadap Pelaksanaan Tanggung Jawab Sosial Perusahaan di Indonesia belum memiliki mekanisme dan aturan yang jelas, siapa yang seharusnya mengawasi pelaksanaan tanggung jawab sosial perusahaan tersebut.

Yang menjadi Pertanyaan besar adalah bagaimana hukum dapat menerapkan sanksi bagi pelanggar aturan kalau tidak ada mekanisme atau prosedur yang jelas kalau pelaku tersebut melanggar aturan?, sedangkan system pengawasan nya tidak ada, akibatnya hukum tidak dapat melihat apakah mekanisme pelaksanaan Tanggung Jawab Sosial Perusahaan tersebut sudah tepat sasaran program sesuai yang diamanatkan oleh peraturan perundang-undangan dan lingkungan masyarakat setempat atau tidak. ${ }^{8}$

Dalam Pasal 4 Peraturan Pemerintah Nomor 47 Tahun 2012 Tentang Tanggung Jawab Sosial dan Lingkungan Perseoran Terbatas menyebutkan :

"Tanggung jawab sosial dan lingkungan dilaksanakan oleh Direksi berdasarkan rencana kerja tahunan perseroan setelah mendapat persetujuan Dewan Komisaris atau RUPS sesuai dengan Anggaran Dasar Perseroan, kecuali ditentukan lain dalam peraturan perundang-undangan"

Berdasarkan ketetuan tersebut, pengawasan Tanggung Jawab Sosial Perusahaan hanya terbatas pada Organ Internal Perusahaan itu sendiri. ${ }^{9}$ Sangat tidak tepat jika melihat dari ketentuan UndangUndang Nomor 40 Tahun 2007 tentang perseroan terbatas, Organ Perseroan Terbatas adalah RUPS, Direksi, dan Dewan Komisaris diminta untuk mengawasi dirinya sendiri yang dalam prakteknya mempunyai tujuan yang sama untuk mencari keutungan sebesar-besarnya dan menimalisir kerugian, karena sejatinya korporasi didirikan oleh para pemegang saham untuk mencari keuntungan. ${ }^{10}$ Oleh karena itu memberikan kewajiban kepada korporasi untuk melaksanakan CSR dianggap bertentangan dengan tujuan utama korporasi, yaitu mencari keuntungan.

Akibat keterbatasan aturan akan mekanisme pengawasan tersebut berdampak pada implementasi CSR itu sendiri, beberapa persoalan konflik sosial perusahaan terkait CSR yang pernah terjadi di Indonesia: PT. Freeportt di Jaya Pura: PT. Inti Indrayon di Porsca Sumatera Utara; PT. Samsung di Pasuruan; PT. Exon Mobil di Lhoksuemawe Aceh; PT. Newmont di Sulawesi Utara. ${ }^{11}$ PT. Freeport

6 Risalah Rapat Panitia Khusus, Rancangan Undang-Undang Tentang Perseroan Terbatas, Masa Sidang III, Kamis Februari 2007 di dalamm buku Mukti Fajar ND, Tanggung Jawab Sosial Perusahaandi Indonesia... Ibid. Hal 1

7 Badan Pembinaan Hukum Nasional Departemen Hukum dan Ham Republik Indonesia, Tanggung Jawab Sosial Perusahan,... op.cit hal 4

8 Muhammad Iqbal, Pengawasan Implementasi Corporate Social Responsibility (CSR) PT. Inalum Terhadap Masyarakat dan Lingkungan Sekitar Perusahaan, 2009, Skripsi, Fakultas Hukum Universitas Sumatera Utara,

$9 \quad$ Ibid.

10 Ian B. Lee, "Corporate Law, Profit Maximization, and The "Responsible" Share Holder", Stanford Journal of Law, Business and Finance, 10 (Spring,2005): 35 di dalam buku Mukti Fajar ND, Tanggung Jawab Sosial Perusahaandi Indonesia.. op.cit. hal 43

11 Hartini Retnaningsih, Permasalahan Corporate Social Responsibility (CSR) Dalam Rangka Pemberdayaan Masyarakat The Problem on Corporate Social Responsibility (CSR) for Community Empowerment, Jurnal Aspirasi Vol 6 No. 6 , 
indonesia yang beroperasi sejak tahun 1969, sampai kini tidak lepas dari konflik berkepanjangan dengan masyarakat tempat selaku Stakeholder, baik terkait dengan tanah ulayat, pelanggaran adat, maupun kesenjangan sosial dan ekonomi yang terjadi. ${ }^{12}$ Kasus Pencemaran Teluk Buyat (pembuangan tailing ke dasar laut) akibat operasional PT.Newmont Minahasa Raya (NMR) tidak hanya menjadi masalah nasional, namun internasional. ${ }^{13}$ Konflik akibat pencemaran lingkungan dan masalah sosial terkait operasional PT. Caltex Pacific (CPI) di wilayah Duri Provinsi Riau, masyarakat menuntut kompensasi hingga tingkat DPR. ${ }^{14}$ Berdasarkan sumber dari beberapa penelitian masih banyak perusahaan yang menjalankan CSR-nya hanya untuk meningkatkan image perusahaan, bahkan ada beberapa perusahaan yang sama sekali tidak mau menjalankan $C S R .^{15}$

Penting halnya mengkaji bagaimana pendekatan teori hukum reflexive (reflexive law theory) dalam menjawab permasalahan keterbatasan pengawasan terhadap pelaksanaan tanggung jawab sosial perusahaan (Corporate Social Responsibility) di Indonesia. Teori reflexive law ini digunakan mengatasi kebuntuan atas pendekatan formal terhadap kewajiban perusahaan dalam sistem hukum serta menjawab permasalahan keterbatasa pengawasan terhadap pelaksanaan tanggung jawab sosial perusahaan (Corporate Social Responsibility) di Indonesia.

\section{Perumusah Masalah}

Berdasarkan uraian latar belakang diatas, maka kajian ini merumuskan permasalahan bagaimanakah pendekatan teori hukum reflexive (reflexive law theory) dalam menjawab Permasalahan Keterbatasan Pengawasan Terhadap Pelaksanaan (Corporate Social Responsibility) di Indonesia?

\section{Pembahasan}

\section{Teori Hukum Refleksif (Reflexive Law Theory) Dalam Menjawab Permasalahan Keterbatasan Pengawasan Terhadap Pelaksanaan (Corporate Social Responsibility) di Indonesia}

Keterbatasan pengawasan terhadap pelaksanaan tanggung jawab sosial perusahaan (Corporate Social Responsbility) di indonesia seperti yang telah dijelaskan diatas akan dikaji melalui pendekatan Teori Hukum Refleksif (Reflexive Law Theory) guna mencari solusi yang tepat dalam menyelesaikan konflik normatif yang telah terjadi.

Teori hukum tentu berbeda dengan apa yang kita pahami dengan hukum positif. ${ }^{16}$ Ini perlu dipahami guna menghindarkan kesalahpahaman, bahwa seolah-olah tidak dapat dibedakan diantara keduanya. Ada kajian filosofis di dalam teori hukum sebagaimana dikatakan Radbruch bahwa, tugas teori hukum adalah membikin jelas nilai-nilai oleh postulat-postulat hukum sampai kepada landasan filosofisnya yang tertinggi. ${ }^{17}$ Menurut Hans Kelsen teori tentang hukum seperti halnya ilmu adalah mengurangi kekacauan dan meningkatan kesatuan (unity), teori hukum adalah ilmu, bukan kehendak atau keinginan. ${ }^{18}$

Teori reflexive law ini digunakan mengatasi kebuntuan atas pendekatan formal terhadap kewajiban perusahaan dalam sistem hukum. Hukum formal yang dimaksud adalah bentuk intervensi Negara dalam mengatur Persoalan privat melalui aturan perundang-undangan, seperti Undang-Undang Ketenagakerjaan, Undang-Undang Lingkungan Hidup, Undang-Undang Perlindungan Konsumen dan sebagainya.

\section{Desember 2015}

12 Wibisono, 2007 dalam Rahmatullah, Rahmat, 2010. "Masalah Pengelolaan Program CSR Pada Sektor Pertambangan," Http:/www.rahmatullah.net/2010/05/masalah-pengelolaan-program-corporate.html, di akses 2 februari 2017

13 Leimona, 2008, Ibid.

14 Mulyadi, 2003, Ibid.

15 Ibid.

16 Menurut Satjipto Raharjo, teori hukum boleh disebut disebut sebagai kelanjutan dari usaha mempelajari hukum positif, setidaknya-tidaknya dalam urutan yang demikian itulah kita merekontruksi kehadiran teori hukum secara jelas. Lihat: Satjipto Rahardjo, ilmu hukum, Citra aditya bakti, Bandung. 1996, hal. 253.

17 Lihat pandangan Wolfgang Freidmann dalam bukunya Legal Theory, London, Stevens \& Sons, 1953. Lihat juga dalam Satjipto Rahardjo, Ilmu Hukum, op.cit., hal. 254

18 Mukthie Fadjar, Teori Hukum Kontemporer, Malang: Setara Press, 2013 hal 11 
Istilah "Hukum Refleksif" pertama kali diperkenalkan kembali pada tahun 1982 oleh Gunther Teubner. ${ }^{19}$ Secara ringkas dapat dikatakan bahwa rematerilisasi adalah kecendrungan di bidang hukum dari rasionalitas formal ke rasionalitas substantif, atau pemisahan dari formalitas hukum sebagai konsekuensi logis paham negara kesejahteraan (welfare state) maupun negara pengatur (regulatory state). ${ }^{20}$

Rogowskip menyebutkan bahwa:

"Reflexive law theory has initally been proposed by Gunter Teubner as a neo evolutionary theory of law in society. It refers to a new evolutionary stage of law, in which law realizes its systemic limits with respect to regulation of other social systems. "' 21

Dalam sebuah model evaluasi hukum yang dikembangkan oleh Nonet dan Selznick. ${ }^{22}$ Nonet dan Selznick menganalisis sebuah model mengenai proses perbuahan hukum yang membebankan aturan yang berpusat pada "dinamika internal" sistem hukum. Dengan model ini maka aturan-aturan hukum hanya berada pada penguatan-penguatan yang mengatur di dalam lingkungan hukum itu sendiri saja. Hal ini berarti bahwa rematerialisasi hukum ini hanya memperbaiki kondisi hukum itu saja, terlepas dari apakah hukum itu mempunyai dampa yang langsung atau tidak kepada berbagai masalah seperti ekonomi, masyarakat, dan budaya. Penguatan yang berpusat pada hukum ini akan memperkuat bentuk hukum yang ada pada sisi pembuat hukum itu sendiri sehingga kecenderungan yang akan muncul adalah hukum sulit diterima secara menyeluruh oleh masyarkat sebab orientasi yang dimuat dalam model ini hanya menjadikan hukum sebagai produk yang otonom.

Oleh karena itu, pendekatan neo-evolusioner dengan hukum refleksif oleh Teubner diarahkan kepada satu perspektif proses perubahan hukum dan sosial. Menurutnya, teori Nonet dan Selznick dalam menggunakan hukum tidak banyak memasukkan campur tangan masyarakat sehingga hukum hanya berkembang tanpa masyarakat. Melalui rematerialisasi hukum, perlu dilakukan perubahan dalam hukum dan masyarakat yang bersifat evolusioner dimana hukum dapat bekerjasama dengan gambarangambaran sosial, ekonomi dan organisas politik dalam suatu masyarakat. Dengan demikian, hubungan antara struktur-struktur hukum dan sosial akan membantu untuk memahami transformasi dalam masyarakat.

Ketika dikaji secara detail, maka akan dapat diperoleh persamaan dan perbedaan gagasan Luhman dan Habermas dengan Nonet dan Selznick. Persamaanya adalah keduanya mengusung pola perubahan/ evolusi. Sedangkan perbedaannya adalah perubahan-perubahan hukum yang ditawarkan oleh Nonet dan Selznick bersandar pada variabel-variabel internal sistem hukum, sementara Habermas dan Luhman menekankan pada inter-relasi eksternal antara hukum dan struktur sosial. Dan Teubner berupaya mempertemukan kedua pendapat tersebut. ${ }^{23}$

Reflexive law theory digunakan sebagai pisau analisis untuk memberi solusi atas adanya permasalahan keterbatasan pengawasan terhadap pelaksanaan tanggung jawab sosial perusahaan (Corporate Social Responsibility) di indonesia. Selanjutnya dijelaskan bahwa reflexive law theory adalah teori hukum yang menjelaskan adanya keterbatasan hukum (limit of law) dalam masyarakat yang kompleks untuk mengarahkan perubahan sosial secara efektif. Untuk mengatasi berbagai keterbatasan

19 Gralf-Peter Calliess, Lex Mercatoria: A Reflexive Law Guide To An Autonomous Legal System, 2001, Hal 2-3, http:// www.germanlawjournal.com/article.php?id=109, di unduh 10 Februari 2018, dengan merujuk pada Karya G. Teubner, Reflexive Recht, 1982 di dalam Romi Librayanto, "Perspektif Hukum Refleksif Terhadap Putusan Mahkamah Konstitusi Nomor 102/PUU-VII/2009” Jurnal Imu Hukum Ammanna Gappa, Vol. 20, Maret 2012, hal 11

20 Hukum dan Masyarakat, http://sandtya.student.umm.ac.id/2010/01/29/hukum-dan-masyarakat/. Hal 1, di unduh tanggal 10 Februari 2018. Di dalam Romi Librayanto, "Perspektif Hukum Refleksif... ibid hal 12

21 Stijn Smismans, Reflexive law in support of directly deliberative polyarchy: Reflexivede liberative polyarchy as a normative frame for the OMC, hlm. 2, http://www.smismans.eu/pdf/RDP\%20Simon\%20 Olivier\%20final.incl.pdf, di unduh tanggal 10 februari 2018. Di dalam Romi Librayanto, "Perspektif Hukum Refleksif... ibid hal 11

22 Nonet, Philippe dan Philip Selznick, Hukum Reponsif Pilihan di Masa Transisi, (Terj. Rafael Edy Bosco) Jakarta: Huma, 2003

23 Romi Librayanto, "Perspektif Hukum Refleksif Terhadap Putusan Mahkamah Konstitusi Nomor 102/PUU-VII/2009" Jurnal Imu Hukum Ammanna Gappa, Vol. 20, Maret 2012, hal 13 
hukum tersebut lahirlah teori hukum reflexive. ${ }^{24}$

Reflexive law theory mencoba untuk menekan kerumitan dan keberagaman masyarakat melalui peraturan perundang-undangan yang ekstensif. Reflexive law theory bertujuan untuk mengarahkan pola tingkah laku dan mendorong pengaturan sendiri (self regulation). ${ }^{25}$ Teori hukum ini memfokuskan pada proses sosial secara "regulated autonomy" yaitu: membiarkan private actors, seperti korporasi untuk bebas mengatur dirinya sendiri. Di sisi lain hukum reflexive mengintervensi proses sosial dengan membuat prosedur acuan untuk perilaku korporasi. ${ }^{26}$

Gunther Teubner mengatakan bahwa telah terjadi evousi hukum yang menghasilkan 3 tipe hukum, yaitu: formal, subtantive, dan reflexive. ${ }^{27}$ Hukum formal adalah bentuk otorisasi pemerintah mengatur melalui perundang-undangan. Tipe ini mengalami kendala bagi pemerintah untuk mengintervensi persoalan-persoalan privat. Sementara, hukum subtantif adalah bentuk intervensi negara pada tujuan dan hasil yang diingikan walau lebih permissive (longgar) dari pada hukum formal, titik fokus hukum substantive menekankan atas hasil yang di inginkan dari regulasi. ${ }^{28}$ Namun hukum subtantif mempunyai dua kendala untuk diterapkan dalam masyarakat yang komplek, yaitu; cognitive limitation dan normative legitimacy. ${ }^{29}$ Gunther Teubner menyebutkan dengan istilah "crisis of the interventionist state" (krisis intervensi negara). Krisis ini merupakan hasil dari ketidakmampuan hukum substantive untuk memenuhi permintaan dari berbagai persoalan masyarakat yang terus berubah. Jika dipaksakan untuk mengikuti perubahan dalam masyarakat maka akan memunculkan produk hukum yang terlalu banyak yang justru akan menyusahkan pemahaman masyarakat.

Terkait dengan CSR, makna tanggung jawab sosial yang berorientasi pada proses yang berhubungan dengan konsep respons sosial korporasi. Respons sosial mengacu pada "kapasitas sebuah korporasi untuk merespon tekanan-tekanan sosial". ${ }^{30}$

\section{Pendekatan Hukum Relfexive Membentuk Konsep Laporan Sosial (Social Reporting) Dalam Pengawasan Pelaksanaan Tanggung Jawab Sosial Perusahaan (Corporate Social Responsibility) di Indonesia}

Dalam hal pengawasan terhadap pelaksanaan CSR, Reflexive law theory adalah teori hukum yang berupaya mendorong korporasi untuk menilai kembali pratek-praktek yang telah mereka lakukan dengan memberikan informasi yang mutakhir. Dalam mengontrol perilaku korporasi, reflexive law theory menghendaki adanya social accounting, auditing dan reporting yang disebut social reporting laporan sosial adalah bentuk laporan singkat mengenai dampak sosial dari perilaku korporasi secara etika terhadap kepentingan masyarakat atau stakeholders. ${ }^{31}$

Tujuan dari regulasi yang berdasarkan Reflexive law theory bukan untuk menyebabkan korporasi melakukan "defensive compliance", tetapi untuk mendorong manajemen yang proaktif dan responsif terhadap persoalan sosial. Laporan sosial harus merupakan kewajian untuk semua perusahaan dengan

24 Gunther Teubner, Subtantive and Reflexive Elements in Modern Law, Law and Society Review, Volume 17, Number 2, 1983) Kuliah Teori Hukum Magister Ilmu Hukum Fakultas Hukum Universitas Islam Indonesia Prof. Guntur Hamzah, S.H., M.H. Tanggal 4 November 2017

25 David Hess, "Social Reporting: A Reflexive Law Approach To Corporate Social Responsiveness", Journal of Corporation Law, 25 (Fall 1999) 42

26 Ibid. Hal 50

27 Ibid. Hal 48

28 Teubner's example of contract law illustrates the difference between these two types of laws. Under Formal, if there is a contractual dispute, the law will only look to see if certain elements establishing a valid contract have been met, such as whether there was mutual assent (offer and Acceptance). Under subtantive law, however, the law may actually alter the terms of the parties' contract to ensure that certain socially-desired outcome are archieved, Ibid., 48-49

29 (1) Cognitive limitation refers to the problem of too much regulatory law, which Teubner has termed "juridification". Cognitive limitation is reached when society becomes too complex for effective control by intervention. (2) Normative legitimacy refers to the "separation of lawmaking from democratic procedures that contributes to the legitimacy of the system. "with the proliferation of various subtantive laws, legislators can become unable to competenly coordinate and reconcile statutes that may affect the same regulated behavior, but in different ways. Futhermore, complex regulations often result in giving agencies greater discretion in enforcing and interpertating the law. Ibid., hal. 49-50.

$30 \quad$ Ibid. Hal 52

$31 \quad$ Ibid. Hal 64 
ukuran tertentu. Baik untuk korporasi publik maupun privat, agar dapat memperoleh dampak yang signifikan pada stakeholders. Akan tetapi, biaya-biaya untuk CSR dan membuat sebuah laporan sosial mungkin terlalu besar untuk perusahaan-perusahaan kecil. ${ }^{32}$

Selanjutnya dalam hal pengawasan pelaksaan CSR, David Hess menawarkan Reflexive Law Theory sebagai pendekatan untuk mencari jalan keluar bagi regulasi CSR. Korporasi diberi kewajiban untuk mengatur dirinya sendiri dalam memperhatikan persoalan sosial dan memberikan laporan dalam memperhatikan persoalan sosial dan memberikan laporan kepada masyarakat, dan selanjutnya, biarlah masyarakat yang akan memberikan penilaianya. ${ }^{33}$

Pasal 60 ayat (1) Undang-Undang Nomor 40 Tahun 2007 tentang Perseroan terbatas, telah mewajibkan bagai direksi untuk menyampaikan laporan tahunan kepada RUPS setelah di telaah oleh Dewan Komisaris. Laporan tersebut menurut ayat (2) haru memuat beberapa hal. Dimana salah satunya adalah laporan mengenai pelaksanaan tanggung jawab sosial dan lingkungan. Namun pasal tersebut tidak memberikan kewajiban bagi perseroan untuk memberikan laporan kepada masyarakat umum.

Gagasan ini sebenarnya bukan hal yang baru. Dalam Good Corporate Governance (GCG), sudah diatur mengenai prinsip- prinsip tata kelola perusahaan yang baik, prinsip-prinsip tersebut adalah $^{34}$ : (1) Tranparansi; Adalah prinsip keterbukaan informasi, baik dalam proses pengambilan keputusan maupun dalam mengungkapkan informasi material dan relevan dalam perusahaan. (2) Akuntabilitas; Adalah kejelasan fungsi, struktur, sistem dan pertanggungjawaban organ perusahaan sehingga pengelolaan perusahaan menjadi efektif. (3) Responsibilities; Adalah kesesuaian di dalam pengelolaan perusahaan terhadap prinsip korporasi yang sehat serta peraturan perundang-undangan yang berlaku; (4) Independensi; Adalah suatu keadaan dimana perusahaan dikelola secara profesional tanpa benturan kepentingan dan pengaruh tekanan dari pihak manapun yang tidak sesuai dengan prinsip korporasi yang sehat serta peraturan perundang-undangan yang berlaku. (5) Kesetaraan dan Kewajaran (fairness);Fairness adalah perilaku yang adil dan setara didalam memenuhi hak-hak stakeholder yang timbul berdasarkan perjanjian atau perundang-undangan.

Penerapan GCG juga berfungsi untuk menumbuhkan kepercayaan investor dan pasar secara umum terhadap perusahaan. Fungsi lainnya adalah untuk mengendalikan perilaku pengelola perusahaan agar tidak bertindak hanya untuk kepentingan diri sendiri. Tetapi juga harus memperhatikan kepentingan shareholders dan stake holder. ${ }^{35}$

Praktek tersebut telah dilakukan di berbagai negara, bahkan secara tegas telah diarakahkan pada pelaksanaann CSR. Sebagai contoh, New York Stock Exchange memiliki Dow Jones Sustainability Indek (DJSI) bagi saham-saham perusahaan yang dikategorikan memiliki nilai Corporate Sustainability dengan salah satu kriterianya adalah praktek CSR. Begitu pula London Stock Exchange yang memiliki Socially Responsible Investment Index (SRI Index) dan Financial Times Stock Exchange (FTSE) yang memiliki FTSE4Good sejak 2001. ${ }^{36}$

Setiap korporasi, khususnya korporasi yang go publik sudah sering dilakukan proses Audit Keuangan untuk melihat kesehatan keuangan perusahaan. Dalam CSR, muncul gagasan agar korporasi melakukan "Audit Sosial" untuk melihat efektifitas dan kredibilitas jalanya program CSR. Korporasi tidak cukup hanya mencakup pengumpulan informasi tentang keuangan perusahaan, melainkan pula aspek lingkuangan dan bahkan kondisi sosial ekonomi masyarkat. Para pekerja sosial (social worker), konsultan atau analisa kebijakan biasanya melakukan audit sosial (social audit) ini.

32 Section $12(\mathrm{~g})$ dari the Securities Exchange Act of 1934 di Amerika Serikat mempersyarakatkan semua korporasi dengan 500 atau lebih Stakeholders dan lebih dari 5 juta dollar assetnya untuk regristrasi ke Securities Exchange Commission dan memenuhi semua persyaratan untuk melakukan keterbukaan (informasi), ibid., hal 66

33 David Hess, "Social Reporting: A Reflexive Law Approach To Corporate Social Responsiveness", Journal of Corporation Law, 25 (Fall 1999): 63

34 Daniri juga mengajukan konsep bahwa CSR sebagai bentuk kepedulian korporasi terhadap persoalan sosial masyarakat adalah bagian dari penerapan prinsip-prinsip CGC, Mas Achamd Daniri, Good Corporate Governance, Konsep dan Penerapannya di Indonesia (jakarta: Ray Indonesia, 2005), hal. 9 -12

35 Joni Emirzon, Prinsip-Prinsip Good Corporate Governance: Paradigma Baru Dalam Praktek Bisnis Indonesia, Yogyakarta: Genta Press, 2007, hal 43-44

36 Mas Achmad Daniri, "Standarisasi Tanggung Jawab Sosial Perusahaan" Hal. 1 di unduh dari http://www.madani-ri. com/2008/01/17/standarisasi-tanggung-jawab-sosial-perusahaan-bag-iii/ 
Walaupun gagasan tersebut cukup relevan, tetap edi suharto menjelaskan bahwa, proses audit sosial memerlukan komitmen yang kuat dari orang-orang kunci, seperti CEO dan Boad of Director pada organisasi yang diaudit. Dalam implementasinya, audit sosial juga memerlukan keterlibatan stakeholders, termasuk pekerja, klien, voluntir, pendiri, kontraktor, supplier dan pendudukan setempat yang terkait dengan operasi perusahaan. Para auditor sosial biasanya bekerja sama dengan shareholders dan stakeholders untuk merancang, mengumpulan,, mengkoordinasikan, dan menganalisis informasi. Metode penelitian yang digunakan melibatkan survey, wawancara, bookeeping dan bahkan studi kasus. ${ }^{37}$

Beberapa persoalan dalam audit sosial tidak hanya terletak dalam kompleksitas perumusannya, tapi juga dalam implementasinya. Audit sosial melibatkan aspek lingkungan dan sosial yang relatif lebih sulit dirumuskan dan dikutu daripada aspek finansial. Audit sosial ini memerlukan ahli yang mempunyai kompetensi komprehensif di bidang lingkungan dan sosial, serta kemampuan menerapkan sebagai metode penelitian. ${ }^{38}$

Kesulitan utama dalam merancang sistem audit terhadap program CSR yang standar adalah merumuskan variabel dan indikator yang tepat dan dapat diterapkan kepada seluruh sektor. Dua syarat utama yang perlu dipenuhi adalah ${ }^{39}$ : (1) Definisi berbagai kategori harus dapat diterapkan terhadap semua perusahaan, industri, dan bahkan sistem sosial yang memungkinkan analisis kompratif. (2) Kategori untuk mengklasifikan keberlangsungan kegiatan perusahaan dalam kurun waktu tertentu sehingga perbandingan historis dapat dilakukan.

Senada dengan Edi Suharto, Ikhsan dan Ishak menyatakan bahwa informasi mengenai tanggung jawab sosial dapat diketahui jika perusahaan menerapkan akutansi sosial. Akutansi sosial dalam hal ini berarti identifikasi, mengukur dan melaporkan antara bisnis dan lingkungannya. Lingkungan di sini meliputi sumber daya alam, komunitas dimana bisnis beroperasi, orang-orang yang dipekerjakan, pelanggan, pesaing dan perusahaan serta kelompok lain yang berurusan dengan bisnis tersebut. Akutansi ssial berperan dalam menghasilkan informasi mengenai biaya dan manfaat sosial. Hanya saja sulit untuk menentukan mana yang merupakan biaya dan manfaat sosial itu sendiri dan kemudian mengkuantifikasi seluruh pos-pos yang relevan dengan biaya dan manfaat sosial tersebut. ${ }^{40}$

Sebagai pembading, global reporting Iniatiative menekankan pentingnya enam prinsip yang perlu diperhatikan dalam mebuat audit sosial dalam pelaporan CSR yang baik, yaitu: ${ }^{41}$ (1) Accuracy: Informasi harus lengkap dan cukup detail agar bisa dinilai oleh pemangku kepentingan secara jelas, tepat dan akurat. (2) Balance: seimbang yang mencerminkan aspek-aspek positif dan negatif dari kegiatan CSR yang dilakukan. (3) Comparability: aspek atau variabel yang digunakan dan dilaporkan harus konsisten sehingga dapat dibandingkan antar waktu. (4) Clarity: Informasi harus tersedia dalam bentuk yang mudah dipahami dan bisa diakses oleh pemangku kepentingan. (5) Realibility: informasi harus ajeg dan terpercaya yang dikumpulkan, direkam, dianalisis, dan disajikan berdasarkan cara atau metodologi yang dapat dipertanggung jawabkan. (6) Timeliness: laporan dibuat secara reguler dan tersedia tepat waktu bagi pemangku kepentingan dan pihak-pihak lain yang memerlukan.

Berdasarkan pada reflexive law theory, CSR dapat diwajibkan oleh pemerintah kepada setiap korporasi. Karena CSR tumbuh dan berkembang sesuai dengan perkembangan bisnis dan reaksi pasar, maka aturan dan mekanisme yang diterapkan adalah dengan mewajibkan korporasi untuk membuat laporan kepada masyarakat (Social Reporting).

Selanjutnya biarkan masyarakat yang memberikan reward and punishmetn, seperti boikot atau kampanye anti korporasi yang tidak menjalankan CSR. Hal tersebut akan efektif apabila masyarakat mempunyai kesetaraan kekuatan untuk bairganing, seperti yang dilakukan LSM-LSM internasional di negara-negara maju, Green Peace misalnya.

37 Edi Suharto, “Audit CSR”, Majalah Bisnis \& CSR, Vol 1 No. 5 , April 2008. Hal 208-209

38 Sebagai Ilustrasi, The Social Economic Agency di Irlandia Utara mulai mempromosikan audit sosial sejak tahun 1996. Konsultan eksternal dilibatkan untuk merancang metodologi audit sosial dan memberikan pelatihan dan pendampingan terhadap para auditor di masing-masing organisasi. Audit sosial pertama dilakukan setelah pelatihan dan monitoring terhadap 10 organisasi. Proses ini memerlukan antara 18 sampai 24 bulan, ibid hal.209

39 Ibid.

40 Ikhsan dan Ishak (2005) dalam Yenni Mangoting, "Biaya Tanggung Jawab Sosial Sebagai Tax Benefit

41 Edi Suharto, “Audit CSR”... op.cit., hal. 213- 214. 
Yanti Koestor dari indonesia business link setuju dengan pendapat tersebut hanya saja, apakah hubungan antara masyarakat dan korporasi telah berimbang. Dia mengatakan:

"saya setuju dengan ide tersebut. Tetapi bergantung pada jenis masyrakat dan perusahaannya apakah mampu/siap atau tidak untuk saling berhadapan. Jika attitude yang dianut adalah "kemitraan" seharusnya tidak ada masalah. Tapi mungkin perlu waktu untuk mengubah pola pikir masyarakat dan korporasi tentang CSR." ${ }^{42}$

\section{Simpulan}

Reflexive law theory adalah teori hukum yang menjelaskan adanya keterbatasan hukum (limit of law) dalam masyarakat yang kompleks untuk mengarahkan perubahan sosial secara efektif. Untuk mengatasi berbagai keterbatasan hukum tersebut lahirlah teori hukum reflexive. dalam hal pengawasan terhadap pelaksanaan CSR, Reflexive law theory adalah teori hukum yang berupaya mendorong korporasi untuk menilai kembali pratek-praktek yang telah mereka lakukan dengan memberikan informasi yang mutakhir. Dalam mengontrol perilaku korporasi, reflexive law theory menghendaki adanya social accounting, auditing dan reporting yang disebut social reporting laporan sosial adalah bentuk laporan singkat mengenai dampak sosial dari perilaku korporasi secara etika terhadap kepentingan masyarakat atau stakeholders.

\section{Daftar Pustaka}

Daniri, M. A, 2005, Good Corporate Governance, Konsep dan Penerapannya di Indonesia. Jakarta: Ray Indonesia.

Emirzon, J, 2007, Prinsip-Prinsip Good Corporate Governace: Paradigma Baru dalam Praktek Bisnis Indonesia. Yogyakarta: Genta Press.

Fadjar, Mukthi, 2013, Teori Hukum Kontemporer. Malang: Setara Press.

Indonesia, Badan, 2009, Pembinaan Hukum Nasional. Tanggung Jawab Sosial Perusahaan. Pustaka Pelajar: Badan Pembinaan Hukum dan Ham Republik Indonesia,

Iqbal, Muhammad, 2009 Pengawasan Implementasi Corporate Social Responsibilty (CSR) PT. Inalum Terhadap Masyarakat dan Lingkungan Sekitar Perusahaan, Medan: Skripsi Fakultas Hukum Universitas Sumatera Utara.

Philipe, Nonet., \& Selznick, 2003, Phillipe. Hukum Responsif Pilihan di Masa Transisi (Terj Rafael Edy Bosco). Jakarta: Huma.

N.D, Mukti. Fajar. 2009, Tanggung Jawab Sosial Perusahaan di Indonesia Mandatory vs Voluntary Studi Tentang Penerapan Ketentuan Corporate Social Responsibility Pada Perusahaan Multi Nasional, Swasta Nasional dan Badan Usaha Milik Negara. Yogyakarta: Pustaka Pelajar.

Raharjo, Sajipto, 1996, Ilmu Hukum.: Bandung: Citra Adiya Bakti.

Salman, HR. Otje., \& Susanto, Anton. F, 2004, Teori Hukum Mengingat, Mengumpulkan dan Membuka Kembali. Bandung: PT Refika Aditama.

42 Mukti Fajar ND, Tanggung Jawab Sosial Perusahaan di Indonesia Mandatory vs Voluntary Studi Tentang Penerapan Ketentuan Corporate Social Responsibility Pada Perusahaan Multi Nasional, Swasta Nasional dan Badan Usaha Milik Negara, (Yogyakarta: Pustaka Pelajar,2009,) hal 324. 


\section{Jurnal}

Retnaningsih, Hartini. Permasalahan Corporate Social Responsibility (CSR) Dalam rangka Pemberdayaan Masyarakat The Problem on Corporate Social Responsibility (CSR) for Community Empowerment, Jurnal Aspirasi, Vol 6 No 6. 2015.

Hess, David. Social Reporting: A Reflexive Law Approach To Corporate Responsiveness, Journal Of Corporation Law 25, 42. 1999. (Daniri, 2005) (Emirzon, 2007)

Librayanto, R. (Vol. 20 2012). Perspektif Hukum Refleksif Terhadap Putuan Mahkamah Konstitusi Nomor 102/PUU-VII/2009. Jurnal Imu Hukum Ammanna Gappa, 11. 